\title{
IMPOSSIBILITY OF PERFORMANCE ASSUMPTION OF RISK OR ACT OF SUBMISSION?
}

\author{
Gilbert A. Cuneo* and Eldon H. Croweld†
}

[I]n the not too distant past, while perhaps foreseeable, no organization would have thought possible, or undertaken a contract to construct a device whereby a living human body could be put in orbit around the earth; nevertheless, it has been accomplished. Thus, in this case, we cannot categorically say that it was or is impossible to achieve the goal called for in plaintiff's contract. ${ }^{1}$

$\ldots \ldots$

We believe that an experienced contractor who accepts a fixed-price contract to produce an item never before made under performance type specifications assumes the risk that performance may be impossible. ${ }^{2}$

\section{I}

\section{INTRODUCTION}

Although the large majority of contracts, both in dollar amount ${ }^{3}$ and in number, ${ }^{4}$ involve procurement by the Department of Defense through negotiated contracts, ${ }^{5}$ the Congress of the United States continues to request more and more fixedprice procurement. Secretary of Defense Robert S. McNamara recently declared to the House Committee on Armed Services:

A major cause of cost overruns on major development programs has been the lack of detailed advanced planning which is an absolute prerequisite for the close pricing of contracts and the close supervision of contractor performance In great part this in-

- A.B. 1934, St. Vincent College (Latrobe, Pa.); LL.B. 1937, Harvard University. Member of the New York and District of Columbia bars; partner in the firm of Sellers, Conner \& Cuneo; Chairman, Public Contracts Division, American Bar Assaciation. Contributor to legal periodicals. Author, Government Contracts Handiook (1962).

† A.B. 1948, Princeton University; LL.B. I951, University of Virginia; member of the Connecticut and District of Columbia bars; partner in the firm of Sellers, Conner \& Cuneo. Contributor to legal periodicals.

The authors wish to acknowledge the assistance of Thomas H. Truitt, an Associate in the firm of Sellers, Conner \& Cunco, and a member of the Virginia bar.

${ }^{2}$ The Austin Co. v. United States, $3 \mathrm{I}_{4}$ F.2d 518, $5 \mathrm{rg}$ (Ct. Cl. 1963 ).

${ }^{2}$ Hol-Gar-Mfg Co., ASBCA No. 6865, 62 BCA $355^{x}$ at $x 8.008$; motion for reconsideration denied, February 5, 1964.

${ }^{3}$ Pilson, Negotiated Contracts, I8 FED. B.J. 126, 127 (1958), wherein the author states that over $80 \%$ of the dollars involved in procurement by the Department of Defense was spent under negotiated contracts. Sec generally, How to Improve Federal Procedures for Buying National Defense Materials, Report to Senator George A. Smathers, Prepared by His Military Procurement Advisory ComMITTEE CC. I and IV (I96I).

'In 1962, out of over 7.5 million transactions entered into by the Department of Defense, $95 \%$ were negotiated under one of the I7 exceptions set out in ro U.S.C. $\$ \$ 2304$ (a) (I)-(I7) (1958). Contracts involving less than $\$ 2,500(80 \%)$ and purchases outside the United States $(9 \%)$ accounted for most of this bulk. Turning from number of transactions to dollar figures, out of 28.I billion dollars spent via defense contracts, $87 \%$ was spent through the medium of negotiated contracts.

"Pilson, supra note 3 . 
adequate planning and control in the past was made possible by the widespread use of CPFF contracts. ... Such open-ended arrangements also incur premature initiation of development projects.

....

It was clear that prompt and firm action would have to be taken to reverse this trend and, accordingly, the military departments were directed to limit CPFF contracts primarily to exploratory research and study projects. ${ }^{6}$

Periodic reports from the Office of the Secretary of Defense on progress being made toward the ultimate goal of maximum fixed-price, competitive procurement by the Defense establishment are required. As a further step in this direction, twostep procurement ${ }^{7}$ was recently initiated by the Department of the Air Force ${ }^{8}$ at the suggestion of the Subcommittee for Special Investigation of the House Armed Services Committee." It was devised "to increase the use of advertising procedures in situations where negotiation would ordinarily be required because technical specifications are not sufficiently definite to assure that all bidders will be offering to supply items meeting the particular need of the Government."10 Under this procedure the ultimate contract is fixed price rather than a cost-plus-fixed-fee.

Congress urges the procuring departments to make a higher and higher percentage of their contracts fixed price; these same procuring departments in turn issue internal directives calling for more and more fixed-price procurement. However, fixed-price contracts follow in many instances where such procurement is not appropriate. $^{11}$ This may result in a fixed-price supply contract which should have been a cost-plus-fixed-fee research and development contract. Space age contracting does not readily lend itself to fixed-price supply contracts, and yet the political pressure as well as a presumed economic pressure demands more certainty as to the cost of the space age products. Courts and boards have found it possible to grant relief in such difficult situations when the contractor finds it cannot perform in the manner contemplated by the parties at the time the fixed-price supply contract was signed. ${ }^{\mathbf{1 2}}$ Unfortunately, in two isolated instances the Court of Claims and the Armed Services Board of Contract Appeals (ASBCA), without analyzing the policies of Congress and the procuring departments, have stated in language not necessary to the de-

"Statement by Secretary of Defense Robert S. McNamara, in Hearings Before the House Comm. on Armed Services, on Military Posture and H.R. 9673, No. 36, 88th Cong., 2d Sess. 7097-98 (1964). See also H.R. REP. No. 1138,88 th Cong., 2 d Sess. 47,48 ( 1964$)$. Secretary McNamara states that between 1955 and $196 \mathrm{r}$ the volume of cost-plus-fixed-fee (CPFF) contracts almost doubled, reaching a peak of $38 \%$ of the total value of awards in the first 9 months of $196 \mathrm{x}$. That percentage figure dropped to $20.7 \%$ of total awards in the fiscal year 1963. The trend is still downward, aiming toward a goal by the cnd of the fiscal year 1965 of $12.3 \%$.

${ }^{7}$ Armed Services Procurement Regulation (ASPR) 2-50r, 32 C.F.R. $\$ 2.01$ (I96r).

${ }^{8}$ Cuneo \& Crowell, Negotiated Contracts, Two-Step Procurement, Cost and Pricing Data Requirements and Protests to the Comptroller General, 5 B.C. Indus. \& CoMM. L. REv. 43, 50-52 (1963).

'Subcomm. for Special Investigation of House Armed Services Comm., Report on Study of Armed Services Procurement Act, 85th Cong., rst Sess. 652 (1957).

$10_{2}$ Government Contractor $\$ 386$ (ig6o).

11 To say that no one need contract with the government avoids the issue. In addition, it is simply not practicable for the government to do no contracting with private parties.

${ }^{12}$ See, e.g., F. J. Stokes, ASBCA No. 6532, 1963 BCA I 3944. 
cision that a contractor assumes the risk of non-performance in signing a fixed-price supply or research and development contract. ${ }^{13}$ If the philosophy of these two cases is followed, the government will achieve a greater percentage of fixed-price contracts but at the expense of creating a host of new and vexing legal problems.

To say "the Appellant gambled and lost"14 is not a satisfactory solution. This article will suggest a possible approach by which space age fixed-price impossibility cases can be analyzed without resorting to "the Appellant gambled and lost" theory (denying relief) or to the "essence of equity, which is the peculiar product of English and American jurisprudence."15 The ordinary standards of contract law or even government contract law may not now be sufficiently developed to properly interpret and apply space age impossibility to the fixed-price contracts now being demanded by both Congress and the executive department. ${ }^{16}$

The terms used in both the ASBCA decisions and Court of Claims decisions cover the same concepts of non-performance. For example, each may use the following terms interchangeably-antecedent impossibility, ${ }^{17}$ intervening impossibility, ${ }^{18}$ practical production impossibility, ${ }^{10}$ faulty specifications, ${ }^{20}$ implied warranty, ${ }^{21}$ beyond the state of the art, ${ }^{22}$ assumption of risk, ${ }^{23}$ and so on. Each of these phrases has its place in the non-performance of a contract; but analyzing the cases in these terms alone may not be productive since the ultimate result will often depend upon the terms adopted in the discussion of the facts or the law; and in turn the basic facts may arouse either antagonism ${ }^{24}$ or sympathy ${ }^{25}$ in the particular board or court.

Neither the common law nor the Restatement furnish the necessary tools for an adequate analysis of space age impossibility under fixed-price contracts. ${ }^{26}$ Only by recognizing the vastly superior bargaining power of the government which often

${ }^{13}$ See The Austin Co. v. United States, supra note I, and Hol-Gar Mfg. Co., supra note 2.

14 Consolidated Avionics Corp., ASBCA Nos. 6315 and 6433, I963 BCA 13888 .

${ }^{16}$ Dillon v. United States, I40 Ct. Cl. 508, 513, I56 F. Supp. 719 (I957).

10 Two excellent recent articles dealing with the more important impossibility cases are Pettit, Impossibility of Performance, Briefing Papers, Government Contractor, No. 63-I (I963); Nash, Impossibility of Performance, Government Contractor Monograph No. 4, George Washington University (1962). For a discussion of the Court of Claims decisions, see 49 VA. L. Rev. 773, 829-33 (1963).

${ }^{17}$ R. M. Hollingshead Corp. v. United States, I24 Ct. Cl. 68I, III F. Supp. 285 (I953) where the Court of Claims decided the case on "mutual mistake as to a material fact." See also, Union Elec. Mfg. Co., ASBCA No. 381r, 58-2 BCA I I966 (1958).

${ }^{18}$ Gittlin Bag Co., ASBCA No. II36 (I953) wherein the Board, quoting extensively from the RESTATEMENT, CONTRACTs $\$ 457$ and $\$ 46 \mathrm{I}$ (1932), sustained an appeal on the basis of "supervening impossibility."

${ }^{10}$ Pastushin Indus., Inc., ASBCA No. 7663, BCA 93757 ( 1963 ); National United States Radiator Corp., ASBCA No. 3972, 59-2 BCA If 2386 (I959); Robbins Mills, Inc., ASBCA No. 2255 (1956).

${ }^{30}$ Helene Curtis Indus., Inc. v. United States, No. 25I-56, Ct. Cl., February 6, I963.

${ }^{21}$ R.M. Hollingshead Corp. v. United States, supra note I7.

${ }^{23}$ L. \& O. Research and Development Corp., ASBCA Nos. 3060 and 5013, 57-2 BCA I 1519 (I957), 59-I BCA I 2 ro7 (x959).

${ }^{23}$ Hol-Gar Mfg. Co., supra note 2.

${ }^{24}$ Dynatran Electronics Corp., ASBCA No. 837 1 , I963 BCA $\{4006$.

${ }^{25}$ Dillon v. United States, I40 Ct. Cl. 508 , I56 F. Supp. 7 I9 (I957).

${ }^{20}$ This is true in spite of the incredible flexibility of the common law of contracts. See Llewellyn, Book Review, 52 Harv. L. REv. 700, 704 (I939). "[T] he potentialities inherent in the common law system for coping with contracts of adhesion have not been fully developed." Kessler, Contracts of Adhesion, 43 Colum. L. Rev. 629, 633 (I943). 
transforms a government contract into an act of submission by the contractor, can these agreements be construed to achieve the equitable results desired under contract law.

II

\section{Impossibility at Common LAW}

Pacta sunt servanda-contracts should be performed-is a basic premise of the common law. However, when an event occurs subsequent to the formation of a contract (intervening impossibility) or a pre-existing fact is discovered which makes performance under the contract impossible (antecedent impossibility), the promisor may be excused. ${ }^{27}$

The doctrine of impossibility of performance originated with three early English cases. $^{28}$ In the first of these cases, the Court of King's Bench stated that where a promisor undertakes to deliver wheat before a certain day to a foreign country and before that day the delivery is made illegal by statute, his promise is discharged. ${ }^{20}$ Queen's Bench, in Hyde v. The Dean of Windsor, said by way of dictum that where a contract requires performance by the promisor, no action will lie for its breach if the promisor dies before fulfilling his obligation. ${ }^{30}$ And it was clearly held in Williams v. Lloyd $d^{31}$ that the bailee of a horse was discharged from his unqualified promise to return the horse when, without fault on his part, it became sick and died.

Since the common law adopted a strict view requiring contracting parties to foresee adverse circumstances, ${ }^{32}$ these early cases became exceptions to the position established in the somewhat later English case of Paradine v. Jane: ${ }^{33}$

When the law creates a duty or charge, and the party is disabled to perform it without any default in him, and hath no remedy over, there the law will excuse him... . But when the party by his own contract creates a duty or charge upon himself, he is bound to make it good, if he may, notwithstanding any accident by inevitable necessity. ...

This statement apparently flatly denies impossibility as a defense in an express promise. $^{34}$ This rule was followed and applied in all its strictness until the middle of the nineteenth century. At that time the courts of England ${ }^{35}$ and the United

${ }^{27}$ See 6 Corain, Contracts $\$ \$$ r320-72 (I95I) [hereinafter cited as Corbin]; Roy G. McELRoY, IMpossibiltiy of Performance (Williams ed. 194I); 6 Williston, Contracts, $\$ 5$ 193I-79 (rev. ed. r938) [hereinafter cited as WiLLIston].

${ }^{28}$ McElroy, op. cit. supra note 27, at 5; Page, The Development of the Doctrine of Impossibility of Performance, I 8 Mich. L. Rev. 588, 591-92, 60I (1920).

${ }^{90}$ Abbot of Westminster v. Clerke, I Dy. 26 b, 73 Eng. Rep. 59, 63 (K.B. 1536), whercin the court cites Y.B. I3 Hen. IV, 36 (I4I2) as authority.

${ }^{30}$ Cro. Eliz. 552, 78 Eng. Rep. 798 (Q.B. 1597).

${ }^{31}$ W. Jones 179, 82 Eng. Rep. 95 (K.B. I629).

32 WiLIISTON $\$$ I931.

${ }^{33}$ Aleyn' 26, 82 Eng. Rep. 897 (K.B. I647).

84 Where death of the promisor renders performance by him impossible and his particular performance was expressly promised and bargained for, the common law excused non-performance. Hyde v. Dean of Windsor, supra note 30 . The cases falling into this category are explained on the theory that continued life is necessary by reason of the character of performance to be rendered. Conoin $\$ 1334$.

${ }_{35}$ Taylor v. Caldwell, 3 B. \& S. 826, r22 Eng. Rep. 309 (K.B. I863) where it was held for the first 
States, apparently moved by the inequities of such a strict rule, admitted additional exceptions. This relaxation was allowed on the theory that it was an implied condition of every contract that subsequent impossibility of performance caused by certain circumstances was a valid excuse and that, when a party to a contract was thus held not to be liable, the intentions of the contracting parties were merely being given effect. $^{30}$

Based on these early English decisions and the application of this theory, nonperformance has been excused in this country in three broad classes of cases. Where, subsequent to the making of the contract, there is a change of law which makes performance legally impossible, ${ }^{37}$ or where an agreement has been made to perform personal services and before the time of performance death or sickness overtakes the party who was to perform, ${ }^{38}$ or where the continued existence of the subject matter is essential to performance of the contract but before the time of performing the subject matter was destroyed by accident without fault on the part of the obliger, ${ }^{39}$ the promisor is excused from his obligation.

While all of these examples constitute intervening impossibility of performance, and not the discovery of a pre-existing fact, no useful purpose is served by drawing a distinction between unknown antecedent impossibility and supervening impossibility. ${ }^{40}$

\section{III}

\section{The Restatement Synthesis}

Based upon the often conceptually diverse early English cases and American decisions too numerous to cite, the American Law Institute's Restatement of Contracts has sought to synthesize a detailed set of rules keyed to the phrase "impossibility of performance."

The Restatement position evolves from its definition of "impossibility." This includes not only strict "impossibility" but also severe "impracticability."

time that the destruction or non-existence of inanimate subject matter to which a contract related would excuse the promisor from liability.

${ }^{30}$ Ibid. See also CoRBin $\$ \mathrm{I} 33 \mathrm{I}$.

${ }^{37}$ Scovil v. McMahon, 62 Conn. 378, 26 Atl. 479 (1892); Cordes v. Miller, 39 Mich. 581 (x878).

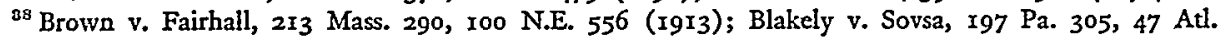
286 (I 1900 ).

${ }^{30}$ Virginia Iron \& Coke Co. v. Graham, 124 Va. 692, 98 S.E. 659 (19x9), and cases cited therein.

${ }^{10}$ WiLlistoN $\$ 933$ states: "If unknown to both parties there is little occasion to distinguish existing impossibility from supervening impossibility. Parties deal with unknown present situations on the same basis as future contingent occurrences, and the law of contracts should adopt this method of dealing with them." Corbin $\$ 1326$ concurs. See also Restatement, Contracts $\$ 401$ (I932) [hereinafter cited as RESTATEMENT].

11 RestateMENT $\$ \$ 454-469$ (I932).

43 Restatement $\$ 454$; Conbin $\$ 1325$, wherein the author describes several types of impossibility, including objective, subjective, impracticable and legal impossibility. Williston suggests classification by type of case. Thus the following situations may give rise to a good defense: ( $\mathrm{I}$ ) impossibility due to domestic law, (2) impossibility due to death or illness of one who by the terms of the contract was to render personal performance, (3) impossibility due to destruction or change in character of something to which the contract related. A fourth debatable category comprises cases where impossibility is due to the failure of some means of performance, contemplated but not bargained for. WiLLISTON $\$$ I935. 
definition excludes "subjective impossibility" which is defined as impossibility "not due to the nature of the performance, but wholly due to the inability of the promisor ...." Th Thus the essential difference between "impossibility" which will excuse performance and "subjective impossibility," which will not, is the distinction between "the thing cannot be done" and "I cannot do it."

The Restatement provides for existing impossibility, stating that "a promise imposes no duty if performance of the promise is impossible because of facts existing when the promise is made of which the promisor neither knows nor has reason to know"45 and places the assumption of risk on the promisee as follows:

Parties may bind themselves by contract to perform what is in fact impossible. It is only where the promisor has no reason to know of the facts to which the impossibility is due, and where he does not agree to bear the risk of their existence that the formation of a contract is prevented. Parties deal with reference to unknown existing facts in the same way that they do with supervening events, and so does the law. Risk is not assumed by a promisor unless, on an interpretation of the contract in the light of accompanying circumstances and usages, an intention is manifested that it shall be assumed. Otherwise the risk is on the promisee. . $^{46}$

The Restatement does not elaborate further on the assumption of risk in the above situation. It is appropriate to note, however, that where neither party has knowledge of the antecedent impossibility and neither party expressly assumes the risk the courts engage in an equitable balancing of all facts in the dispute. ${ }^{47}$

Additionally, the Restatement divides "supervening impossibility" into several categories. First, performance may be excused when made illegal by legislative act or by "judicial, executive or administrative order ...."49 Second, death or illness of the promisor, where his particular performance was bargained for, will excuse performance. ${ }^{50}$ Third, the "non-existence or injury of a specific thing or person necessary for performance, or the material deterioration of such a specific thing, negates the duty of performance under the contract." ${ }^{31}$

${ }^{13}$ Restatement $\$ 455$. See Corbin $\$ 1328$; Williston $\$$ I927A.

\& RESTATEMENT $\$ 455$, comment $a$. This position is supported in Corbin $\$$ r325, and WiLListoN $\$ 1932$.

${ }^{45}$ Restatement $\$ 456$; Corbin fully supports this proposition citing the Restatement section. Condin $\$ 1326$. While both the Restatement and Corbin state that such is the state of the law, Williston suggests that it should be the state of the law. Wriliston $\$$ I933, 1935 .

${ }^{15}$ Restatement $\$ 456$, comment $c$. Illustration No. 4 states: "A, a general contractor, contracts with $B$ to build a bridge according to plans that have been prepared by $C$, a bridge engineer, cmployed by $B$. The determination of the sufficiency of the plans demands expert knowledge. They are so defective that a structure built according to them must inevitably fall before it is half finished. It does so when A has partially completed it. A is under no duty, since performance was from the outset impossible. He had no reason to know this and did not, on a fair interpretation, agree to bear the risk of the expert's incompetence." R. M. Hollingshead Corp. v. United States, I24 Ct. Cl. 681, II I F. Supp. 85 (1953), is an excellent example of this situation.

${ }^{2}$ CORBIN $\$ 1328$; WILLISTON $\$ 1972 A$.

${ }^{6}$ Restatement $\$ 457$; CoRbin $\$ 1321$.

¿ Restatement $\$ 458$ (b); Corbin $\$$ 1343; Williston $\$$ 1939. See also Gittlin Bag Co., ASBCA No. 1336 (1953).

$\checkmark 0$ RestateMent $\$ 459$.

${ }^{51}$ Restatement $\$ 460$; CoRBin $\$ \$ 1337,1338$. 
Although these three subdivisions of "supervening impossibility" constitute the traditional view of the English and American cases, the Restatement additionally provides for the situation where the non-existence of particular facts makes performance impossible. ${ }^{\mathbf{2} 2}$ And while no specific reference is made to the non-existence of scientific information, the Restatement comments:

There is no tenable reason for allowing a discharge for the nonexistence of a tangible specific thing that by the terms of a contract or the contemplation of the parties is essential to its performance, and denying a discharge where other means of performance similarly essential or contemplated cease to exist..$^{53}$

Other sections of the Restatement dealing with impossibility continue to treat the subject liberally in discussing temporary ${ }^{54}$ and partial ${ }^{55}$ impossibility.

\section{IV}

\section{Court of Claims and Impossibility}

Indeed, what is there that does not appear marvelous when it comes to our knowledge for the first time? How many things, too, are looked upon as quite impossible until they have been actually effected? ${ }^{56}$

Most of the cases decided by the Court of Claims dealing with impossibility can be rationalized into a pattern. The results in each individual case can be justified and placed in their proper niche in the greater scheme of impossibility. ${ }^{57}$

R. M. Hollingshead Corp. v. United States, ${ }^{58}$ is generally considered to be the leading case of actual, objective, antecedent, or "specification" impossibility. In that case the plaintiff agreed to supply a certain quantity of twenty-five per cent DDT concentrate in five-gallon metal drums. The concentrate was required by the contract to remain clear and not become cloudy for a period of one year under certain conditions. ${ }^{59}$ Because of the interaction of the concentrate and the metal of the containers, the liquid rapidly lost its clear color and became cloudy. Neither party knew at the time the contract was signed that the specification requiring a metal container and the specification requiring clear color after storage could not both be met. This, therefore, presented a clear case of "objective impossibility."

Plaintiff sued for the contract price of $\$ 28,428$.15. The government had withheld amounts otherwise due on the contract on the basis that plaintiff corporation had

${ }^{53}$ Restatement $\$ 46 \mathrm{I}$; CoRbin $\$ 1339$.

${ }^{53}$ RestaTEMENT $\$ 46 \mathrm{x}$, comment $a$.

5. RESTATEMENT $\$ 462$.

Et RESTATEMENT $\$ 463$.

${ }^{50}$ C. Plinius Secundus [Pliny the Elder], Natural History Bk. VIII, sec. 5 (H. Rackham ed. 1938).

${ }^{57}$ See 49 VA. L. REV. 773, 829 et seq. (1963).

${ }^{68} 124$ Ct. Cl. 68I, III F. Supp. 285 (1953).

${ }^{\text {to }} \mathrm{It}$ is interesting to note that in $\mathrm{I} 948$ when this contract was signed DDT concentrate was a relatively new and unknown product.

${ }^{00}$ See Cordin § 1325 . 
failed to comply wtih the contract specifications. In denying the government's motion to dismiss, the Court of Claims stated:

... it would be a rare instance when the supplier could reasonably be expected to investigate for himself whether compliance with the specifications would in fact, produce the desired results. ${ }^{61}$

Impossibility on such a clean set of facts is not difficult to achieve conceptually, but in earlier decisions the court embraced the doctrine of "extreme hardship" within the Restatement doctrine of impossibility.

In Mitchell Canneries, Inc. v. United States, ${ }^{62}$ plaintiff agreed to deliver 18,000 dozen \# Io cans of blackberries. Thereafter, due to adverse weather conditions (an exceptionally rainy season) in Florida, it became impossible to make further deliveries. Subsequently, the government made purchases in Oregon and Washington. The contracting officer found that plaintiff's failure to deliver was due to unforeseeable causes beyond the control and without the fault or negligence of the contractor within the meaning of the delays-damages provision of the contract. ${ }^{03}$

The General Accounting Office (GAO) withheld the excess costs of repurchase from money otherwise due plaintiff under several subsequent contracts which had been successfully performed. The Comptroller General ruled that there was no legal basis for relieving the contractor from responsibility. ${ }^{04}$ The court neatly sidestepped the traditional argument that great difficulty is not impossibility (the blackberries were in fact obtained) by declaring:

If the doctrine that a contractor may not be excused when materials are available anywhere, at any price, were carried to its logical conclusion, it would follow that there would have to be complete crop failure over the entire surface of the world before a contractor would be relieved from damages. ${ }^{65}$

Therefore, extreme difficulty is equated with impossibility, in substance if not in form. ${ }^{60}$

Almost ten years later the "shield" protecting plaintiff against excess costs for non-performance in the Mitchell case ${ }^{67}$ was turned into a sword to recover excess costs for performance due to extreme hardship. In Dillon v. United States, ${ }^{88}$ plaintiff

${ }^{61} \mathrm{I}_{24} \mathrm{Cr}$. Cl. 68I, 683-84 (1953). As support for this statement the court cites Spearin v. United States, 5 I Ct. Cl. I55, aff'd, 248 U.S. I32 (1918); Steel Products Engineering Co. v. United States, 71 Ct. Cl. 457 (r93I); and Whitlock Coil Pipe Co. v. United States, 72 Ct. Cl. 473 (I93I).

${ }^{6}$ III Ct. Cl. 228, 77 F. Supp. 498 (I948).

${ }^{63} I d$. at 244,245 . The Department of Agriculture had found that the heavy rains had shortened the crop. However, in Carmen v. United States, 143 Ct. Cl. 747, I66 F. Supp. 759 (1958), a severe flood was not sufficient to shift the added cost of performance from plaintiff to the government under either the changes or changed conditions provisions of the standard form construction contract. Impossibility as such was not discussed.

Bs Id. at 248 .

${ }^{\mathrm{OS}} \mathrm{Id}$. at $250,25 \mathrm{r}$.

${ }^{\circ o}$ This case did not, however, involve request for relief by plaintiff, but rather involved a defense of nonperformance-plaintiff had a shield, not a sword.

${ }_{67}$ II I Ct. Cl. 228, 77 F. Supp. 498 (I948).

${ }^{68}$ I 40 Ct. Cl. 508, 156 F. Supp. 7I9 (1957). 
sued for the excess costs it incurred in successfully performing a contract to deliver hay to the government in Oklahoma. Because of a severe drought in the area, plaintiff was unable to secure the hay required. Plaintiff repeatedly requested release from its obligations; the government repeatedly insisted on full performance. Hay was ultimately obtained by plaintiff from Nebraska at a much greater cost.

The court depicted this severe drought in graphic terms: "The hot winds come and sweep with blistering trail across the prairies. The heavens become like brass and the earth as iron. The small streams go dry, the leaves wither and the growing grass becomes seared."

The court recognized the general rule that difficulty of performance or loss in carrying out a contract will not be treated as a basis for relief by the courts. Nevertheless, the court felt constrained, under the circumstances, to grant partial relief for the excess cost of the Nebraska hay, relying heavily on the Mitchell ${ }^{0}$ case. After stating the general rule, the court declared:

But in extraordinary cases where extreme hardship, unforeseen and not contemplated by either party, would necessarily result, a measure of relief may be granted if the unusual circumstances justify such action. This is the very essence of equity, which is the peculiar product of English and American jurisprudence. ${ }^{71}$

Thus, "extreme hardship" becomes impossibility; and plaintiff not only has forged a shield to excuse non-performance because of excessive rain but also has forged a sword to obtain excess costs in performance under extreme hardship because of excessive sun. ${ }^{72}$ This case allows "extreme hardship" impossibility relief by the use of the phrase "the very essence of equity." This phrase, however, would seem sufficient only for the most extreme factual situations. Such an analysis would not serve standard "extreme hardship" or "practical impossibility" situations.

Rolin $v$. United States ${ }^{73}$ is one of the first cases in which the court is faced with a sophisticated, twentieth century, space age impossibility problem. Plaintiff sued for the additional costs it incurred because of extraordinary difficulty encountered in complying with the accuracy the specifications required for the impedance measuring line called for by the contract. The court stated:

The case arises because the plaintiff lost money on the contract due to the fact that he encountered extraordinary difficulty in achieving the necessary dimensional stability in the particular piece of Ni-Resist metal that he used as the base of the impedance measuring line. ${ }^{74}$

The National Bureau of Standards (NBS) wished to obtain an impedance measuring line of greater accuracy than that being then (1948) procured by the Air

${ }^{00} 1 d$. at $5 \mathrm{II}$, $156 \mathrm{~F}$. Supp. at $72 \mathrm{r}$.

${ }^{70}$ II I Ct. Cl. 228, 77 F. Supp. 498 (r948). The court also relied on $\$ \$ 454$ and 460 of the Restatement.

${ }^{71} 140 \mathrm{Ct}$. Cl. 513 .

72 One writer contends that Dillon was merely "an isolated example of recovery." 49 VA. L. REv. 733, $833(1963)$.

${ }_{73}{ }_{142}$ Ct. Cl. 73 (1958).

${ }^{74}$ Id. at 82 . 
Force. It was determined by plaintiff and NBS personnel that the base of the impedance measuring line should be made of Ni-Resist metal. ${ }^{75}$ Bids were requested by NBS from eight suppliers; the invitation required the base to be a casting of non-magnetic Ni-Resist metal. Plaintiff's low bid was accepted.

Plaintiff encountered extraordinary difficulty in the annealing of the Ni-Resist casting. It required four separate annealings instead of the originally contemplated single annealing. The court, however, refused to grant plaintiff's claim for the additional costs on the standard ground that difficulty does not excuse performance. ${ }^{70}$ The court declared:

Therefore the fact that a person who has contracted with the Government to furnish materials or services encounters unforeseen difficulties, and thereby incurs unexpected expenses, in the performance of the contract does not impose upon the Government any legal obligation to relieve its contractor of the unexpected burden.77

The court distinguishes Hollingshead v. United States ${ }^{78}$ on the grounds that the specifications in Hollingshead were objectively impossible of performance and did not merely subject the plaintiff to extraordinary difficulty. ${ }^{79}$ Nor did the court find the specifications actively misleading. ${ }^{80}$ Within the traditional terms of contract law the case may be correct, but represents a more rigid view of impossibility than the court had previously followed.

Closely allied to the extreme hardship cases are the misleading or defective specification cases. ${ }^{81}$ Many of these latter cases could be analyzed by utilizing other theories such as practical production impossibility, ${ }^{82}$ mutual mistake of a material fact, ${ }^{83}$ or even conflicting specification. ${ }^{84}$ In Helene Curtis Indus., Inc. v. United States, ${ }^{85}$ the Court of Claims chose to analyze the facts under two theories-"a failure of the Government to tell what it should" and also "a Government specification which in its context was actively misleading." ${ }^{\text {" }}$ The contract called for plaintiff to supply large quantities of a disinfectant chlorine powder. Chlormelamine, the disinfectant's

${ }^{25}$ Ni-Resist is a proprietary metal alloy developed by the International Nickel Company and is widely used in industry because of its relative stability in relation to other metals. Id. at 76 .

${ }^{20}$ The court quoted with approval the statement in United States v. Spearin, 248 U.S. 132, 136 (Igr8), "where one agrees to do, for a fixed sum, a thing possible to be performed, he will not . . become entitled to additional compensation, because unforeseen difficultics are encountered." But the court fails to quote the very next sentence appearing in that opinion: "But if the contractor is bound to build according to plans and specifications prepared by the owner [as it was in Rolin], the contractor will not be responsible for the consequences of defects in the plans and spccifications."

${ }^{7 \pi} 142 \mathrm{Ct}$. Cl. at $8 \mathrm{r}$.

${ }^{78}{ }_{124}$ Ct. Cl. 68I, II I F. Supp. 285 (1953).

${ }^{70} \mathrm{r} 42 \mathrm{Ct}$. Cl. at 85 .

${ }^{80}$ See Helene Curtis Indus., Inc. v. United States, 312 F.2d 774 (Ct. Cl. 1963).

${ }^{81}$ See Kostos, Ambiguous, Defective, and Conflicting Government Specifications, Government Contracts Monograph No. 4, George Washington University ( 1962 ).

${ }^{82}$ Pastushin Indus., Inc., ASBCA No. 7663, I963 BCA I3757; Robbins Mills, Inc., ASBCA No. 2255 (x950).

${ }^{83}$ Hollingshead, supra note 78.

84 Seaview Elec. Co., ASBCA No. 6966, 6r-2 BCA I 3151 (I96r).

${ }^{85}$ Helene Curtis, supra note 80.

${ }^{80} I d$. at 778 . 
active ingredient, was a new and patented chemical which had never previously been mass produced. ${ }^{87}$ Plaintiff bid on the basis that the disinfectant could be produced by simply mixing chlormelamine with the other ingredients.

Plaintiff ultimately determined that it would be necessary to grind the chlormelamine to reduce its particle size so the disinfectant would meet the solubility standards of the specifications. The additional work caused increased costs. The court stated that "in all probability" the government knew that the expensive grinding would be necessary, that the government specification as it was issued was in its context actively misleading, and that the government had a duty to share this superior information.

In addition to the expensive grinding procedures, plaintiff discovered that its supplier was not shipping individual batches but blending several together for shipment. Because of the very sensitive nature of the ingredient, blended batches would not result in a satisfactory end product. After plaintiff shipped only unblended batches, production continued without further interruption. The court found that the government knew that each batch differed in chlorine content but that there was not a sufficiently close connection between the information withheld and the delayed uncovering of the supplier's manufacturing process. Therefore, no recovery was allowed for the added expense caused by attempting to manufacture the disinfectant from blended batches.

The court analyzed the facts by using the theory of "misleading specification" as well as a government breach of the obligation to disclose information, and stated:

Although it is not a fiduciary toward its contractors, the Government-where the balance of knowledge is so clearly on its side-can no more betray a contractor into a ruinous course of action by silence than by the written or spoken word. ${ }^{88}$

This language could as easily be found in a discussion of extreme hardship impossibility or practical production impossibility as in a discussion of misleading specifications. Helene Curtis never deals squarely with the theory of impossibility; it is suggested, however, that its facts are closely enough allied to many of such cases that a process of analysis which would permit a discussion of all of these cases within the same legal framework would be beneficial.

The Austin Co. v. United States, ${ }^{89}$ a recent decision by the Court of Claims, is certainly correct in its result, but contains the unfortunate language cited at the beginning of this article. The plaintiff entered into a contract to design, manufacture, test and deliver a digital data recording and transcribing system. Such a system had never before been manufactured. Before the execution of the contract, plaintiff thought that the government-prepared specifications would not result in a system of the required precision. It, therefore, submitted a proposal which modified the government's specifications. These modifications were ultimately

\footnotetext{
${ }^{87}$ See National United States Radiator Corp., ASBCA No. 3972, 59-2 BCA If 2386 (1959).

${ }^{88} \mathrm{Id}$. at 778 .

${ }_{314}^{80}$ F.2d 518 (Ct. Cl. 1963).
} 
adopted by the parties and incorporated into the contract. Plaintiff, after expending $\$ 290,000$, determined that it was impossible to manufacture the system to the required precision due to a phenomenon called "jitter."

The court held that plantiff assumed the risks of impossibility of performance since the specifications were its own. The court simply declared: "In other words, plaintiff drew up the specifications and thereby undertook a firm obligation to perform thereunder." $"$ o

But unfortunately the court went further than was required by the facts of the case and stated: ${ }^{21}$

[I]n the not too distant past, while perhaps foreseeable, no organization would have thought possible, or undertaken a contract to construct a device whereby a living human body could be put in orbit around the earth; nevertheless, it has been accomplished. Thus, in this case, we cannot categorically say that it was or is impossible to achieve the goal called for in plaintiff's contract.

This language will cause trouble if literally applied to other cases and the result will not be desirable. In no space age contract can any court ever say that it is "impossible to achieve the goal called for in plaintiff's contract." ${ }^{\text {"2 }}$ This is a true statement; but if it is literally applied, there can be no space age impossibility. Such a result is not desirable. The courts must utilize a more useful tool of analysis. It is submitted that such a tool is already at hand in the concept of a government contract as a contract of adhesion. The necessity for such a tool is also becoming apparent from a reading of the impossibility decisions of the ASBCA.

\section{$\mathrm{V}$}

\section{Development of the Impossibility Doctrine by the Armed Services} Board of Contract Appeals

When you have eliminated the impossible, whatever remains, however improbable, must be the truth. ${ }^{23}$

The Armed Services Board of Contract Appeals, at an early stage, adopted principles similar to those enunciated in the Hollingshead case. ${ }^{94}$ The Board modified and adopted the Hollingshead principles in order to make possible, consistent with its jurisdictional limitations, its granting of relief under appropriate circumstances. The Board has applied many different principles and theories to allow contractors to recover the additional costs resulting from impossibility or extreme impracticability problems encountered in their performance of government contracts. ${ }^{.5}$ Whether

${ }^{\circ}$ Id. at 520.

${ }^{91}$ Id. at 5 I9.

02 Ibid.

${ }^{93}$ Arthur Conan Dotre, The Sign of Four (1890).

94 See, e.g., Globe Crayon Corp., ASBCA No. 1496 (1954).

of Nash, Impossibility of Performance, Government Contracts Monograph No. 4, at 29-34 (Georgc Washington University 1962). 
the Board termed the problem one of excusable delay, ${ }^{96}$ constructive change, ${ }^{97}$ superior knowledge, ${ }^{98}$ difficulty not contemplated by the parties, ${ }^{99}$ defective, ${ }^{100}$ or conflicting $^{101}$ specifications, it found itself able to grant relief for impossibility of performance or practical production impossibility.

In one of its earliest impossibility of performance decisions, Globe Crayon Corp..$^{102}$ the ASBCA allowed the contractor to recover when performance in accordance with the contract provisions proved impractical in commercial quantities with any speed. The contract involved required the contractor, a commercial crayon company with extensive experience in the production of crayons, to manufacture and deliver within a four-month period approximately $75^{0,000}$ crayons containing a government-furnished ingredient which made the crayons suitable for detecting poisonous gases in the air. The contractor discovered that with the addition of the government-furnished ingredient it was unable to produce satisfactorily the required crayons utilizing its standard, mass-production machinery and techniques. Tests conducted by the United States Bureau of Standards revealed that satisfactory crayons could be produced to meet the performance requirements of the contract, but only by utilizing an expensive and time-consuming hand extrusion method.

Relying upon the government-furnished property article of the contract and the fact that the parties obviously intended a mass-production method of performance when the contract was executed, ${ }^{103}$ the Board sustained the crayon company's appeal for additional compensation. This early impossibility case is the first clear expression by the Board that relief would be granted in a situation of practical production impossibility.

In Robbins Mills, Inc., ${ }^{104}$ the Board again allowed recovery for practical production impossibility. The contractor, a textile manufacturer, was required to furnish a large quantity of nylon cloth having specified ballistic properties. Many physical characteristics of the nylon cloth, including the maximum weight per square yard, were specified in the contract and the nylon cloth was required to meet certain ballistic tests. The contractor was unable, on a consistent basis, to produce nylon cloth of the specified maximum weight which would meet the required ballistic tests. In finding that the contractor was entitled to an equitable adjustment for the additional costs which it incurred in producing acceptable nylon cloth, the Board determined that the specified maximum cloth weight limitation created a problem of practical production impossibility:

${ }^{00}$ E. L. Cournand \& Co., ASBCA No. 2955, 60-2 BCA I 2840 (1960).

${ }^{87}$ Robbins Mills, Inc., ASBCA No. 2255 (1956).

${ }^{\text {os }}$ F. J. Stokes Corp., ASBCA No. 6532, I963 BCA q 3944 (I962).

${ }^{\circ 0}$ Globe Crayon Corp., ASBCA No. 1496 (1954).

${ }_{100} \mathrm{~J}$. W. Hurst \& Son Awnings, Inc., ASBCA No. 4I67, 59-I BCA I 2095 (I959).

101 Seaview Electric Co., ASBCA No. 6966, 6I-2 BCA ff 3I5I (196I).

${ }^{103}$ ASBCA No. 1496 (I954).

103 "Here the crayons can be made, and apparently are being made, or have been made by this time, but under circumstances indicative of a radical change in performance, or at least a greatly extended performance, not within the contemplation of the parties at the time they entered into the contract."

${ }^{204}$ ASBCA No. 2255 (I956). 
We further find that the possibility of performance of the contract in compliance with the ballistic specification was reduced as a practical matter to the point of extinction, if the weight dictated by the contract as awarded controlled. . . . Perhaps by the manufacture of yardage in excess of two and one-half times that deliverable under the contract, the contractor could conceivably accomplish performance, but in so doing it would invite financial ruin or disposal imponderables, unless the pricing was prohibitivcly exorbitant. The contractor could have been required to manufacture up to approximatcly $r, 690,000$ yards of surplusage which at average contract price would be valued at approximately $\$ 4,320,000$. We find in the premises that the practical aspects of the contractor's performance problem involved economic impossibility equivalent to absolute impossibility. 105

To effect the desired relief, the Board employed its constructive change technique, finding that a change order relaxing the cloth weight limitation should have been issued at the time the contract was awarded..$^{100}$

From these earlier impossibility cases, through the present time, the Board has continued to grant relief for practical production impossibility and impossibility of performance. In $L \& O$ Research and Development Corp., ${ }^{107}$ the contractor was unable to meet the contract performance requirements for a computer which it had contracted to develop, despite extensive development efforts. The Board found the performance specifications impossible to achieve and granted relief. In one of its most quoted impossibility of performance decisions, 1. W. Hurst \& Son Awnings, Inc., ${ }^{108}$ the Board found that the government specifications for the tents to be manufactured by the contractor were defective; and, on the basis of a constructive change, it allowed the contractor the additional costs which it incurred as a result of the inefficiency and extra work caused by the defective specifications. ${ }^{109}$

In Spencer Explosives, Inc., ${ }^{110}$ the Board again granted relief in a situation of ${ }^{108}$ Id. at I3-I 4 .

200 "In our opinion the facts of this appeal require that a change order be issued. The maximum weight per square yard as fixed by the contract at $\mathbf{1 4 . 2 5}$ ounces was too low. . . We find that the contractor was entitled to a weight relaxation at the time the contract was awarded, and that a change order should have been issued. . . . We direct the issuance of a change order as indicated above."

${ }^{107}$ ASBCA No. 3060, 57-2 BCA I 1514 (1957).

${ }^{103}$ ASBCA No. $4167,59-1$ BCA $\$ 2095$ (1959).

${ }^{109}$ That section of the $J$. W. Hurst decision so frequently quoted in impossibility decisions is:

"When the Government contracts for supplies to be manufactured in accordance with Government specifications, ordinarily there is an implied warranty on the part of the Government that, if the specifications are followed, a satisfactory product will result. United States v. Spearin, 248 U.S. 132; Hollingshead $\nabla$. United States, 124 C. Cls. 68r. . . F Faulty design and mistakes in specifications causing extra work have been held to provide a basis for price adjustment under the 'Changes' clause, Guntert and Zimmerman Construction Division, Inc., ASBCA No. 1544 (1954); White Star Heating \& Supply, Inc., ASBCA No. 2015 (1954); even though the change constituted a relaxation of the specifications to achieve an attainable result. General Electric Company, ASBCA No. 2458, 56-2 BCA Par. ro93; Robbins Mills, Inc., ASBCA No. 2255 (1956); Measurements Corporation, ASBCA No. 2444 (I955). We are of the opinion that this appeal is governed by the principles there enunciated. . . . Where, as here, the change is necessitated by defective specifications and drawings, the equitable adjustment to which a contractor is entitled must, if it is to be equitable, i.e., fair and just, include the costs which it incurred in attempting to perform in accordance with the defective specifications and drawings. General Electric Company, supra; Robbins Mills, Inc., supra. Under these circumstances the equitable adjustment may not be limited to costs incurred subsequent to the issuance of the change orders."

${ }^{110}$ ASBCA No. $4800,60-2$ BCA $\$ 2795$ (1960). 
practical production impossibility. The contractor was to manufacture pyrotechnic flares in accordance with detailed government specification requirements. The Board found that conforming flares could be produced in accordance with the specifications, but that the rejection rate of unsatisfactory flares, due to the government specifications, was too severe for the contractor to be held responsible.

In E. L. Cournand \& Co., Inc., ${ }^{111}$ the contractor was to design and manufacture containers in accordance with government performance requirements. Despite the fact that the contractor had participated, under a previous contract, in drafting the specifications, the Board found that the contractor was entitled to the requested relief because it was impossible to produce the containers to meet the contract, strength, non-leakage, and maximum weight requirements. The Board stated that neither party contemplated an extensive research and development effort and that both parties expected the contract effort to be essentially one of manufacturing. On the basis of these conclusions, the Board found that the contractor, despite its earlier participation in the drafting of the specifications, had not assumed the risk that performance was possible.

The attention in the Cournand decision to the assumption of risk question was probably prompted by the earlier Aerosonic Instrument Corp..$^{112}$ decision which held that the contractor was responsible for performance, on the ground of assumption of risk, in a situation where the contract specifications were impossible of achievement. In Aerosonic, the contractor obligated itself to develop a type of tachometer tester never previously produced, even though it admittedly knew that the state-of-the-art in the industry would have to be advanced to allow successful completion. In view of the recognized developmental nature of the contract, the government had suggested a cost type contract, but the contractor had insisted upon a fixed-price type of contract. Under these circumstances of clear and knowing assumption of risk by the contractor, the Board concluded that the government could not be expected to bear the financial burden of the contractor's folly. ${ }^{113}$

In its more recent decisions, the Board continues to apply the impossibility principles developed in its earlier decisions, although the assumption of risk doctrine, developed in the Aerosonic and Austin cases, appears to have introduced a new difficulty in the Board's method of analysis. In F. J. Stokes Corp. ${ }^{114}$ the contractor undertook to design and manufacture freeze-drying equipment to meet government performance requirements. The freeze-drying equipment was to be utilized in processing a classified biological material, the characteristics of which were not revealed to the contractor until after the execution of the contract. The Board found that the classified material could not be satisfactorily processed in accord-

111 ASBCA No. 2955, 60-2 BCA $\uparrow 2840$ (I960).

${ }^{119}$ ASBCA No. 4129, 59-I BCA $\$ 2115$ (1959).

${ }_{113}$ On a similar clear showing of a knowing assumption of risk, the Board reached similar conclusions in The Austin Co., ASBCA No. 4255, 6r-I BCA If 2927 (I96r).

${ }^{114}$ ASBCA No. 6532, I963 BCA $\mid 3944$ (1962). See also Fenco-Polytron, AEC CA-I7I (April r, 1964). 
ance with the specification performance requirements. Even though the contractor had superior knowledge in freeze-drying techniques, the Board found the government responsible for the performability of the specifications on the basis that the contractor could not have contemplated the extent of the work ultimately required.

The contractor in Pastushin Indus., Inc. ${ }^{115}$ was required to produce aircraft fuel tanks in accordance with government specifications and meeting government testing requirements. The Board found that tanks built to the specification requirements would not consistently pass the required performance tests and determined that the contractor was entitled to the extra costs of attempting to produce fuel tanks which would pass the physical strength test requirements.

In Utah-Manhattan-Sundt, ${ }^{116}$ the appeal was brought by the prime in behalf of its subcontractor Struthers-Wells Corporation. The prime contract called for the construction of the first ICBM launching complex; the subcontract was for the manufacture of the process vessels to be installed at the bottom of the underground silos. Struthers-Wells encountered unexpected difficulties in the manufacture of the gaseous pressure storage vessels. These difficulties were ultimately solved, but at very substantial increase in cost. The solution of some of these difficulties lay beyond the state of the art.

The Board here decided the case as much on the theory of acceleration of work as it did on impossibility of performance. The Board stated that Struthers-Wells had no reasonable means of knowing that processes and welding materials previously used successfully would not meet the requirements of the present specifications. The time required to solve some of these problems which resulted in an advancement in the state of the art, entitled Struthers-Wells to an extension of time. The extra cost incurred in making up for the excusable delay resulted in acceleration costs which were compensable.

The Board also held that the Austin case ${ }^{117}$ in the Court of Claims did not apply because Struthers-Wells did not actually draft the vessel specifications (although it gave certain suggestions); the Board rejected the implied warranty theory on the basis that the government did not possess superior knowledge; and the Board rejected the assumption of risk theory on the basis that Struthers-Wells had no reasonable means of foreseeing the difficulties which actually arose under the performance of the specifications. The Board placed the additional costs under acceleration rather than impossibility.

The Board has, however, denied recovery in other circumstances when it finds that the contractor has assumed the risk. In these cases there is great difficulty since few can show such a clear assumption of risk as the Austin case. At the same time the Board agrees that assumption of risk should not be lightly assumed.

\footnotetext{
${ }^{115}$ ASBCA No. 7663,1963 BCA 93757.

${ }^{110}$ ASBCA No. 899r, r963 BCA I 3839 (1963).

117 The Austin Co. v. United States, $3 I_{4}$ F.2d 518 (Ct. Cl. 1963).
} 
In Hol-Gar Mfg. Co., 118 the Board held, "We believe that an experienced contractor who accepts a fixed-price contract to produce an item never before made under performance specifications assumes the risk that performance may be impossible."110 But is such a contention reasonable? In this case appellant agreed to supply rop trailer mounted diesel generators to be built in accordance with government performance specifications. Due to space limitations the unit overheated and it became obvious that the endurance tests could not be passed. The Board assumed that the government furnished performance specifications were impossible of performance, but held that appellant had assumed the risk of non-performance.

The Board based this determination on the fact that the contractor in its technical proposal assured the government that it could perform. But would not every contractor make such an assurance? And would not the government be negligent if it contracted with a contractor who would not give such assurances? The ultimate question is whether such assurances are sufficient to place the risk of impossibility on the contractor, even assuming the government did not have superior knowledge or did not warrant the performability of its own specifications? It does not seem possible to harmonize this decision with prior and subsequent decisions of the Board in this area.

In Consolidated Avionics Corp. ${ }^{120}$ the Board is again troubled with a similar case and arrives at a similar unfortunate result. The bidder was required, under a contract awarded as a result of an advertised procurement, to provide "an on-line force and readout system for the propulsion wind tunnel, supersonic circuit, located at the Arnold Engineering Development Center." the performance type specifications because the accuracy was beyond the state of the art at the time of performance. The government refused to relax its standards and the contract was terminated for default.

Again the Board assumed the fact of impossibility of performance; again it placed such risk of non-performance on the contractor. The Board's reasoning closely followed the Hol-Gar case. It declared that the contractor was experienced; but should he be deemed to have assumed the risk on the basis of experience? Again even though there is no government warranty of performance type specifications, a fixed-price contract under these circumstances is not sufficient to place the burden of non-performance on the contractor. Such facts are not sufficient to turn the contract into a gambling transaction. ${ }^{122}$

In both of these cases the Board declared that the contractor assumed the risk of impossibility almost by the simple act of signing a space age fixed-price contract containing government-furnished performance specifications. This result would not

${ }^{118}$ ASBCA No. 6865, $62 \mathrm{BCA}$ I 355 I.

${ }^{210}$ Id. at 18,008 .

${ }_{200}$ ASBCA Nos. 6315 \& 6433, I963 BCA ๆ 3888 (1963).

191 Id. at 19, 297.

${ }_{253}$ "The appellant gambled and lost. It should be held to the bargain it made." Id. at pp. 19, 303. But what was that bargain? 
necessarily follow from a different analysis of the facts. It is submitted that the necessity for fixed-price contracts as a matter of both legislative and executive policy requires the courts and the boards to utilize a different tool of analysis when such contracts are impossible to perform.

\section{Government Contracts As Contracts of Adheston}

The law is not so primitive that it sanctions every injustice except brute force and downright fraud. ${ }^{123}$

Traditionally the cases and commentaries have declared that, when the government steps down from its position of sovereignty and enters the domain of commerce, ${ }^{124}$ it submits itself to the same laws that govern the businessman. ${ }^{125}$ Traditionally the cases also state that the rights of the parties under a government contract are to be determined by the application of the same principles as if the contract were between individuals. ${ }^{126}$ Even now the courts will occasionally state that the contractor must turn the same square corners as required of the government. ${ }^{127}$

Most thoughtful commentators now agree, however, that in many areas, government procurement contracts are utilized as instruments to attain national goals which are by consensus considered socially desirable. ${ }^{128}$

The courts are now beginning to recognize that federal procurement can foster social (non-discrimination clause) and economic (Buy American Act) policy ${ }^{120}$ The Court of Claims has recently stated: "[I]t is important now, that procurement policies set by higher authority not be avoided or evaded (deliberately or negligently) by lesser officials, or by a concert of contractor and contracting officer."130

Thus the myth of the government descending to the market place and negotiating like any other businessman is being slowly exploded. Not only the standard clauses are now required to be incorporated into each and every government contract, but also all mandatory contractual regulations are incorporated by reference, regardless of the desires of the contracting parties. ${ }^{131}$ Therefore, the areas of

${ }^{128}$ United States v. Bethlehem Steel Corp., 315 U.S. 289, 326 (1942) (Justice Frankfurter dissenting).

124 The present volume of this "domain of commerce" approximates one hundred billion dollars annually.

${ }^{125}$ See Cooke v. United States, 9I U.S. 389, 398 (1875); Robert P. Shealey, The Laty op Govern• MENT Contracts $\S_{3}$ (3d ed. 1938).

${ }^{136}$ Reading Steel Casting Co. v. United States, 268 U.S. 186, I88 (1924); Smoot's Case, 82 U.S. (15 Wall.) 36,47 (1872).

127 The Austin Co. v. United States, 314 F.2d 518 (Ct. Cl. I963).

${ }^{128}$ See Speck, Enforcement of Nondiscrimination Requirements for Government Contract Work, $G_{3}$ Colum. L. Rev. 243 ( $\mathrm{rg}_{3}$ ); Van Cleve, The Use of Federal Procturement to Achieve National Goals, 196r Wis. L. Rev. 566; Pasley, The Nondiscrimination Clatse in Government Contracts, 43 VA. L. Rev. 837 (1957); Symposium, Compulsory Contracts, 43 Colum. L. Rev. 569-752 (r943).

${ }^{129}$ See G. L. Christian \& Associates v. United States, 312 F.2d 418 , motion for rehearing denied, 320 F.2d 345 (Ct. Cl. 1963 ), cert. denied, 375 U.S. 954 ( 1963 ), rehearing denied, 376 U.S. 929 (1964).

${ }^{180} 320$ F.2d at $35 \mathrm{r}$.

131 Ibid. 
negotiation are becoming more and more restricted. Conditions and clauses in a government contract are on a take-it-or-leave-it basis; there is no freedom of choice. ${ }^{132}$

Government contracts reflect a power relationship, and not a consensual agreement between equals. ${ }^{133}$ In spite of this fact the Court of Claims has been leary of granting relief in cases of economic duress, ${ }^{134}$ although it has indicated that relief would be granted where the government is guilty of deliberate harassment and dilatory tactics even though the contractor finished the work on time. ${ }^{135} \mathrm{~A}$ frank recognition of this power relationship leads to the conclusion that government contracts, just as insurance contracts, are contracts of adhesion. ${ }^{136}$

Kessler, the leading authority, describes contracts of adhesion as follows:

Standard contracts are typically used by enterprises with strong bargaining power. The weaker party, in need of the goods and services, is frequently not in a position to shop around for better terms, either because the author of the standard contract has a monopoly (natural or artificial) or because all competitors use the same clauses. His contractual intention is but a subjection more or less voluntary to terms dictated by the stronger party, terms whose consequences are often understood only in a vague way, if at all. Thus, standardized contracts are frequently contracts of adhesion; they are a prendre ou a laisser. ${ }^{137}$

The usefulness of this concept in analyzing insurance contracts is readily apparent. No longer will the courts need to engage in the sophistry of tort theory to permit a recovery under a contract. "They regard recovery ex contractu as impossible, but at the same time allow recovery ex delictu." 138 It is necessary to discard the usual concepts of offer and acceptance and realize that often "the act of the business firm awarded a government contract is, to a large extent, an act of submission."139

Assuming, therefore, that government contracts are contracts of adhesion, how does this fact aid in the analysis of the multitude of impossibility cases? First, the Congress demands more fixed-price contracts; second, the President and procuring departments agree and conclude a larger percent of fixed-price contracts than ever before; third, such contracts may turn out to be impossible or practically impossible of performance in this space age technology. If these fixed-price contracts are looked upon for what they are, contracts of adhesion, then each should be analyzed on the basis of what the weaker party could legitimately expect in such a fixed-price space age contract and in addition to what extent the stronger party

\footnotetext{
132 The fact that many of the standard clauses are drafted with the advice (and sometimes consent) of the business community does not inject any real element of consent into the contract.

${ }^{133}$ Miller, Government Contracts and Social Control: A Preliminary Inquiry, 4I VA. L. REv. 27, 57 (1955).

${ }^{134}$ See Fruhauf Southwest Garment Co. v. United States, I26 Ct. Cl. 5 I (I953).

${ }^{135}$ Metropolitan Paving Co. v. United States, Ct. Cl. No. 509-58, decided December 13, I963.

${ }^{150}$ See Patterson, The Delivery of a Life Insurance Policy, 33 Harv. L. Rev. 198, 222 (I919).

${ }^{137}$ Kessler, Contracts of Adhesion, 43 Colum. L. REv. 629, 632 (I943).

${ }^{138}$ Id. at 635 .

${ }^{100}$ Miller, supra note 133 , at 57 .
} 
is disappointed in its reasonable expectations based upon normal fixed-price contracts. $^{140}$

Just as there is an implied duty of cooperation in every contract, ${ }^{141}$ there should be an implied duty to require fixed-price contracts only when there is the reasonable expectation that such a method of contracting is proper. If such method proves not to be proper, then relief should be granted the contractor as the weaker party in this contract of adhesion.

\section{VII}

\section{Contracts of Adhesion and Impossibility of Performance}

It is readily apparent from the brief discussion of the cases set forth above that there is no unified or satisfactorily coherent approach to the myriad impossibility cases arising under space age fixed-price contracts containing performance specifications furnished by the government. Many theories are set forth often times to justify a result rather than to analyze the case. In the clear cases it is not difficult to arrive at a correct result.

For example in The Austin Co.v. United States, ${ }^{142}$ the contractor clearly assumed the risk of impossibility of performance under the facts of the case. The contractor's own technical proposal embodying modifications of the government's specifications was incorporated into the specifications when the contract was signed. ${ }^{143}$ It is entirely defensible to hold that the contractor assumed the risk of impossibility.

On the other end of the scale is $J$. W. Hurst \& Son Awnings. ${ }^{144}$ In this case design specifications for tents contained numerous errors. The Board held that "ordinarily there is an implied warranty on the part of the government that, if the specifications are followed, a satisfactory product will result." ${ }^{145}$ It is entirely proper to hold that the government has impliedly warranted its own design specifications. ${ }^{146}$

But what of those cases where the courts and boards are presented with government-furnished design or performance specifications under a fixed-price contract perhaps as a result of congressional and executive pressure for this type of contract? In many cases such contracts obviously are calling for a production item because of the delivery date specified and not for research and development. Neither the

\footnotetext{
${ }^{100}$ Only once has the government argued that it was the weaker, helpless party to a contract and that, therefore, economic duress was imposed on itl United States v. Bethlehem Steel Corp., 315 U.S. 289, 300 (1942).

${ }_{1 \leqslant 1}$ Peter Kiewit Sons Co., Inc. v. United States, ${ }_{3} 8$ Ct. Cl. 668, 674 (1957); Kehm Corp. v. United States, Irg Ct. Cl. 454, 469 (I950); Walter A. Rogers v. United States, 99 Ct. Cl. 393, 410 (1943). ${ }_{142} 314$ F.2d 518 (Ct. Cl. I963).

143 3r4 F.2d at 519.

144 ASBCA 4x67, 59-I BCA \2095 (1959).

${ }^{146} \mathrm{Id}$. at 8964 .

${ }^{140}$ United States v. Spearin, 248 U.S. $\mathrm{r}_{32}, \mathrm{I}_{3} 6$ (1918) states: "[I]f the contractor is bound to build according to plans and specifications prepared by the owner, the contractor will not be responsible for the consequences of defects in the plans and specifications."
} 
contractor, although fully competent in his field, nor the government has superior knowledge. Neither party suspects that performance is beyond the present state of the art or that it may be a practical production impossibility to make the item. Who should bear the risk of impossibility?

If the analysis is made as has been suggested here, then under such circumstances the government would be responsible. In any government contract the weaker party is the contractor. Since this is a contract of adhesion, there is little or no negotiation or give and take regarding the type of contract. There is no assumption of risk but a submission to terms dictated. Therefore, the courts and boards should ask the question, what was it reasonable for the weaker party in the contract of adhesion to expect from the stronger party? Or to turn the question another way, was the stronger party disappointed in its reasonable expectations of performance by the weaker party?

The results would not differ in most of the cases set forth above. But in a few cases such as the Rolin case ${ }^{147}$ in the Court of Claims and the Hol-Gar ${ }^{148}$ and Consolidated Avionics ${ }^{149}$ cases in the Armed Services Board of Contract Appeals, the suggested analysis would result in a contrary conclusion. It is important that both courts and boards re-examine their traditional thoughts about freedom of contract between equal parties. The acceptance by a contractor of a government contract is much more often an act of submission than it is an assumption of risk.

${ }^{167}$ Rolin v. United States, 142 Ct. Cl. 73 (1958).

${ }^{148} \mathrm{Hol}$-Gar, supra note Ir8.

${ }^{240}$ ASBCA Nos. 6315 \& 6433, I963 BCA $\prod_{3} 888$ (I963). 